\title{
SIMULTANEOUS DETERMINATION OF DIPHENHYDRAMINE, EPHEDRINE, NOSCAPINE, AND GLYCEROL GLYCOLATE USING STABILITY-INDICATING HIGH-PERFORMANCE LIQUID CHROMATOGRAPHY: APPLICATION TO NOSCOF TABLETS
}

\author{
PULAGURTHA BHASKARARAO*, GOWRI SANKAR DANNANA
}

Departmentof Pharmaceutical Analysis, College of Pharmaceutical Sciences, Andhra University, Visakhapatnam, Andhra Pradesh, India. Email: bhaskarmph@gmail.com

Received: 24 November 2018, Revised and Accepted: 07 January 2019

ABSTRACT

Objective: Noscof tablet is a fixed dosage combination formulation having diphenhydramine (DH), ephedrine (ED), noscapine (NP), and glycerol glycolate (GG). A sensitive, selective, accurate, precise, and stability-indicating reversed-phase high-performance liquid chromatography (RP-HPLC) method with photodiode array detection has been developed and validated for simultaneous analysis of DH, ED, NP, and GG in bulk drug and Noscof tablets.

Methods: Reversed-phase chromatographic separation and analysis of DH, ED, NP, and GG were done on an Altima C18 column with $0.01 \mathrm{M} \mathrm{KH}_{2} \mathrm{PO}{ }_{4}$ buffer (pH 3.5) and acetonitrile (50:50\%, v/v) as mobile phase at $0.8 \mathrm{ml} / \mathrm{min}$ flow rate in isocratic mode. Detection was performed at $260 \mathrm{~nm}$. The method was validated in harmony with International Conference on Harmonization (ICH) guidelines. The tablet sample solution was subjected to diverse stress conditions using ICH strategy such as hydrolytic degradation (neutral - with distilled water, alkaline - with $2 \mathrm{~N} \mathrm{NaOH}$, and acidic - with $2 \mathrm{~N} \mathrm{HCl}$ ), oxidation (with $10 \% \mathrm{H}_{2} \mathrm{O}_{2}$ ), photodegradation (exposing to UV light), and dry heat degradation (exposing to $105^{\circ} \mathrm{C}$ ).

Results: Using the above stated chromatographic conditions, sharp peaks were obtained for ED, NP, DH, and GG with retention time of 3.272 min, $4.098 \mathrm{~min}, 5.467 \mathrm{~min}$, and $6.783 \mathrm{~min}$, respectively. Good regression coefficient values were obtained in the range of $2-12 \mu \mathrm{g} / \mathrm{ml}$ for ED, $3.75-22.5 \mu \mathrm{g} / \mathrm{ml}$ for NP, 3.125-18.75 $\mu \mathrm{g} / \mathrm{ml}$ for DH, and 25-150 $\mu \mathrm{g} / \mathrm{ml}$ for GG. The quantification limits were $0.181 \mu \mathrm{g} / \mathrm{ml}, 0.187 \mu \mathrm{g} / \mathrm{ml}, 0.246 \mu \mathrm{g} / \mathrm{ml}$, and $1.114 \mu \mathrm{g} / \mathrm{ml}$ for ED, NP, DH, and GG, respectively. The values of validation parameters are within the acceptance limits given by ICH. The ED, NP, DH, and GG showed more percent of degradation in acid condition and less percent of degradation in the neutral condition. The peaks of degradants did not interfere with the peaks of analytes. ED, NP, DH, and GG were assessed with a good percentage of the assay (near to $100 \%$ ) and low percent relative standard deviation $(<2 \%)$ in Noscof tablets using the proposed method.

Conclusion: The stability indicating RP-HPLC method developed was suitable for quantifying ED, NP, DH, and GG simultaneously in bulk as well as in tablet formulation.

Keywords: Noscof, Diphenhydramine, Ephedrine, Noscapine, Glycerol glycolate, Stability, Analysis.

(c) 2019 The Authors. Published by Innovare Academic Sciences Pvt Ltd. This is an open access article under the CC BY license (http://creativecommons. org/licenses/by/4. 0/) DOI: http://dx.doi.org/10.22159/ajpcr.2019.v12i3.30942

\section{INTRODUCTION}

Combination drug therapy involves the use of $\geq 2$ pharmaceutical agents given separately or as a single fixed combination dosage formulation [1]. This therapy is prescribed when there is no proper therapeutic response with monotherapy. Advantages of fixed dosage combination formulation include intake of few pills daily by a patient, reduction of medication errors, and decrease of medication costs, adverse effects of individual pharmaceutical agent are minimized [1-3].

Noscof tablet (manufactured by Medico Labs, Ahmadabad, India) is a fixed dosage combination formulation labeled to have $12.5 \mathrm{mg}$ of diphenhydramine (DH), $8 \mathrm{mg}$ of ephedrine (ED), $15 \mathrm{mg}$ of noscapine (NP), and $100 \mathrm{mg}$ of glycerol glycolate (GG) [4]. DH is a first-generation antihistamine [5]. ED is a central nervous system stimulant [6]. NP is an opium alkaloid having antitussive activity [7]. GG medication is used to treat diarrhea, meningitis, stroke, and encephalitis [8].

Noscof tablet is employed in the management and relief of symptoms of allergy, hay fever, common cold, asthma, decreased blood pressure, cancer of prostate, heart stroke, diarrhea, encephalitis, meningitis, Reye's syndrome, and dry cough [4,9]. Noscof acts as a stimulant for the central nervous system. The activity of Noscof tablet involves blockage of histamine action, cardiac output raise, provoking vasoconstriction, suppression of cough reflex in brain, miniaturization of skin, and hydration of body. Through reducing blood vessels swelling in the nasal passage, Noscof expands the airway and thus improves breathing.

Our investigation is an attempt for developing and validating a reversedphase high-performance liquid chromatographic (RP-HPLC) method to quantify DH, ED, NP, and GG simultaneously in bulk and fixed dosage combined formulation, Noscof. As per our literature survey knowledge, yet no stability indicating analytical method using (RP-HPLC) technique using photodiode array detector (PDA) is reported for the estimation of DH, ED, NP, and GG simultaneously in bulk and fixed dosage combined formulation, Noscof. Hence, this study is aimed to develop a quick, simple, precise, and accurate RP-HPLC method for concurrent estimation of the above said drug combination in bulk and tablet formulation (Noscof). The developed method is validated following guidelines as stated by the International Conference on Harmonization (ICH) [10].

\section{METHODS}

Reference drugs, chemicals, and solvents

The standards of DH, ED, NP, and GG were procured from BMR chemicals and enterprises (Hyderabad, India). Water of HPLC grade (Milli-Q water, Millipore, USA) was used throughout the project. Noscof tablets (Medico Labs, Ahmadabad, India) consisting $12.5 \mathrm{mg}, 8 \mathrm{mg}, 15 \mathrm{mg}$, and $100 \mathrm{mg}$ of DH, ED, NP, and GG, respectively, were purchased and used. 
Acetonitrile of HPLC grade is from Merck Specialities Private Limited (Mumbai, India). Analytical reagent grade potassium dihydrogen phosphate, orthophosphoric acid, hydrochloric acid, sodium hydroxide, and hydrogen peroxide were purchased from Avantor Performance Materials India Limited (Gurgaon, India) and used in this project.

\section{Chromatography apparatus}

The simultaneous analysis of DH, ED, NP, and GG was done using waters HPLC system (model 2695) outfitted with quaternary pumps, autosampler, and PDA detector. The analysis system was examined using Empower 2 software.

\section{Chromatographic condition for the analysis}

For analysis and validation, Altima C18 column, $5.0 \mu \mathrm{m}, 150 \mathrm{~mm}$ $\times 4.6 \mathrm{~mm}$, with a temperature of $30^{\circ} \mathrm{C}$ was used. Isocratic elution was performed with $0.01 \mathrm{M}$ potassium dihydrogen phosphate and acetonitrile mixture (50:50, by volume) at $0.8 \mathrm{ml} / \mathrm{min}$ flow rate. The mobile phase was filtered using Nylon filters $(0.45 \mu \mathrm{m})$ and degassed before use. $\mathrm{pH}$ of $0.01 \mathrm{M}$ potassium dihydrogen phosphate was adjusted to 3.5 with orthophosphoric acid. Eluents were detected and analyzed at a detection wavelength of $260 \mathrm{~nm}$ by injecting $10 \mu \mathrm{l}$ volume.

\section{Standard solutions of DH, ED, NP, and GG}

Stock solution was prepared by dissolving accurately weighed quantities of DH (3.125 mg), ED (2 mg), NP (3.75 mg), and GG (25 mg) in $25 \mathrm{ml}$ of diluent acetonitrile and water mixture (50:50 by volume) in a standard flask of capacity $25 \mathrm{ml} .1 \mathrm{ml}$ of stock solution was diluted with mobile phase to make working solution with concentration $12.5 \mu \mathrm{g} / \mathrm{ml} \mathrm{DH}, 8 \mu \mathrm{g} / \mathrm{ml} \mathrm{ED}, 15 \mu \mathrm{g} / \mathrm{ml} \mathrm{NP}$, and $100 \mu \mathrm{g} / \mathrm{ml} \mathrm{GG}$. Prepared solutions are stored $\left(4^{\circ} \mathrm{C}\right)$ and brought back to room temperature just at the time of use.

\section{Construction of DH, ED, NP, and GG calibration curves}

To prepare calibration samples, appropriate aliquot volumes of stock solution were transferred into a series of $10 \mathrm{ml}$ standard flasks then diluted to volume $(10 \mathrm{ml})$ with mobile phase. The calibration samples have six concentrations of DH (3.125-18.75 $\mu \mathrm{g} / \mathrm{ml})$, six concentrations of ED $(2-12 \mu \mathrm{g} / \mathrm{ml})$, six concentrations of NP $(3.75-22.25 \mu \mathrm{g} / \mathrm{ml})$, and six concentrations of GG $(25-150 \mu \mathrm{g} / \mathrm{ml})$. The calibration samples are injected into Altima C18 column with a flow rate of $0.8 \mathrm{ml} / \mathrm{min}$. The peak area, determined at $260 \mathrm{~nm}$, of DH, ED, NP, and GG was recorded versus their concentration. The linearity curves of DH, ED, NP, and GG was constructed, and regression equations for the selected drugs were calculated.

\section{Analysis of DH, ED, NP, and GG in noscof tablet}

A total number of 10 Noscof tablets were powdered. Tablet powder equivalent to $12.5 \mathrm{mg}$ of $\mathrm{DH}, 8 \mathrm{mg}$ of $\mathrm{ED}, 15 \mathrm{mg}$ of $\mathrm{NP}$, and $100 \mathrm{mg}$ of GG was taken into a $100 \mathrm{ml}$ standard flask, $75 \mathrm{ml}$ of diluent was added followed by sonication for $25 \mathrm{~min}$. After sonication, the volume was made to $100 \mathrm{ml}$ with diluent and filtered through a nylon filter. Concentration of tablet stock solution is $80 \mu \mathrm{g} / \mathrm{ml}-\mathrm{ED}, 150 \mu \mathrm{g} / \mathrm{ml}$ - NP, $125 \mu \mathrm{g} / \mathrm{ml}$ - DP, and $1000 \mu \mathrm{g} / \mathrm{ml} \mathrm{-} \mathrm{GG.} 1 \mathrm{ml}$ of tablet stock solution was diluted to $10 \mathrm{ml}$ with mobile phase in $10 \mathrm{ml}$ standard flask. The final concentration of tablet test solution is $8 \mu \mathrm{g} / \mathrm{ml}$ - ED, $15 \mu \mathrm{g} / \mathrm{ml}-\mathrm{NP}$, $12.5 \mu \mathrm{g} / \mathrm{ml}-\mathrm{DH}$, and $100 \mu \mathrm{g} / \mathrm{ml}-\mathrm{GG} .10 \mu \mathrm{l}$ of the tablet test solution is injected into Altima C18 column with a flow rate of $0.8 \mathrm{ml} / \mathrm{min}$ for analysis. The peak areas of DH, ED, NP, and GG were determined. The concentrations of DH, ED, NP, and GG in Noscof tablet were calculated from the corresponding calibration curves or calculated regression equations.

\section{Degradation studies}

The stability tests were performed on the tablet formulation following the guidelines of ICH $[11,12]$.

\section{Oxidation}

To $1 \mathrm{ml}$ of tablet stock solution $(80 \mu \mathrm{g} / \mathrm{ml}$ - ED, $150 \mu \mathrm{g} / \mathrm{ml}-\mathrm{NP}$, $125 \mu \mathrm{g} / \mathrm{ml}-\mathrm{DH}$, and $1000 \mu \mathrm{g} / \mathrm{ml}-\mathrm{GG}$ ), $1 \mathrm{ml}$ of $10 \%$ hydrogen peroxide was added. The solution was mixed and kept refluxed for $30 \mathrm{~min}$ at $60^{\circ} \mathrm{C}$.

\section{Acid degradation}

About $1 \mathrm{ml}$ of tablet stock solution $(80 \mu \mathrm{g} / \mathrm{ml}-\mathrm{ED}, 150 \mu \mathrm{g} / \mathrm{ml}-\mathrm{NP}$, $125 \mu \mathrm{g} / \mathrm{ml}-\mathrm{DH}$, and $1000 \mu \mathrm{g} / \mathrm{ml}-\mathrm{GG}$ ) is mixed with $1 \mathrm{ml}$ of $2 \mathrm{~N}$ hydrochloric acid and refluxed for $30 \mathrm{~min}$ at $60^{\circ} \mathrm{C}$. After degradation, the solution was neutralized with a sufficient volume of $2 \mathrm{~N}$ sodium hydroxide.

\section{Alkali degradation}

About $1 \mathrm{ml}$ of tablet stock solution $(80 \mu \mathrm{g} / \mathrm{ml}-\mathrm{ED}, 150 \mu \mathrm{g} / \mathrm{ml}-\mathrm{NP}$, $125 \mu \mathrm{g} / \mathrm{ml}$ - DH, and $1000 \mu \mathrm{g} / \mathrm{ml}-\mathrm{GG}$ ) is mixed with $1 \mathrm{ml}$ of $2 \mathrm{~N}$ sodium hydroxide and refluxed for $30 \mathrm{~min}$ at $60^{\circ} \mathrm{C}$. After degradation, the solution was neutralized with a sufficient volume of $2 \mathrm{~N}$ hydrochloric acid.

\section{Dry heat degradation}

About $1 \mathrm{ml}$ of tablet sample solution $(80 \mu \mathrm{g} / \mathrm{ml}$ - ED, $150 \mu \mathrm{g} / \mathrm{ml}-\mathrm{NP}$, $125 \mu \mathrm{g} / \mathrm{ml}-\mathrm{DH}$, and $1000 \mu \mathrm{g} / \mathrm{ml} \mathrm{-} \mathrm{GG)} \mathrm{was} \mathrm{placed} \mathrm{in} \mathrm{oven} \mathrm{at} 105^{\circ} \mathrm{C}$ for $6 \mathrm{~h}$ for dry heat degradation.

\section{Photo stability}

To study the effect of UV light on selected drug combination, $1 \mathrm{ml}$ of tablet sample solution $(80 \mu \mathrm{g} / \mathrm{ml}$ - ED, $150 \mu \mathrm{g} / \mathrm{ml}$ - NP, $125 \mu \mathrm{g} / \mathrm{ml}$ - DH, and $1000 \mu \mathrm{g} / \mathrm{ml}-\mathrm{GG}$ ) was exposed to UV light by placing the solution in UV Chamber for 7 days.

\section{Neutral degradation}

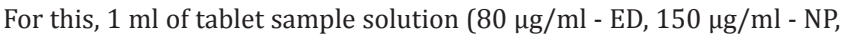
$125 \mu \mathrm{g} / \mathrm{ml}$ - DH, and $1000 \mu \mathrm{g} / \mathrm{ml}$ - GG) was refluxed with $1 \mathrm{ml}$ of water for $6 \mathrm{~h}$ at a temperature of $60^{\circ} \mathrm{C}$.

In all the conditions, the degraded sample solutions were cooled to room temperature and diluted to $10 \mathrm{ml}$ with mobile phase to obtain a working solution ( $8 \mu \mathrm{g} / \mathrm{ml}$ - ED, $15 \mu \mathrm{g} / \mathrm{ml}$ - NP, $12.5 \mu \mathrm{g} / \mathrm{ml}$ - DH, and $100 \mu \mathrm{g} / \mathrm{ml}$ - GG) for analysis. $10 \mu \mathrm{l}$ of the working solution was injected into the system. The corresponding chromatograms were recorded to evaluate the stability of ED, NP, DP, and GG in the applied degradation conditions.

\section{RESULTS AND DISCUSSION}

The current investigation considers the first RP-HPLC-PDA method for simultaneous estimation of ED, NP, DH, and GG. The stability of the selected drug combination was assessed under acid, alkali, oxidative, neutral, thermal, and photo conditions.

\section{Method development}

During optimization process, different columns (BDS C8, $150 \mathrm{~mm} \times$ $4.6 \mathrm{~mm} 5.0 \mu$; discovery C8, $250 \mathrm{~mm} \times 4.6 \mathrm{~mm} 5.0 \mu$; discovery C18, $150 \mathrm{~mm} \times 4.6 \mathrm{~mm} 5.0 \mu$; Kromasil C18, $150 \mathrm{~mm} \times 4.6 \mathrm{~mm} 5.0 \mu$; symmetry C18, $150 \mathrm{~mm} \times 4.6 \mathrm{~mm} 5.0 \mu$; and Altima C18, $150 \mathrm{~mm} \times 4.6 \mathrm{~mm} 5.0 \mu$ ), different organic modifiers (methanol/acetonitrile) proportions, and various buffers (orthophosphoric acid buffer/potassium dihydrogen orthophosphate buffer) with different $\mathrm{pH}$ values $(2.5 / 3.5)$ were tried. As seen in Fig. 1, the good resolution and good peak shapes were obtained using Altima C18, $150 \mathrm{~mm} \times 4.6 \mathrm{~mm} 5.0 \mu$ as an analytical column with $0.01 \mathrm{M}$ potassium dihydrogen orthophosphate buffer, adjusted to $\mathrm{pH} 3.5$ with orthophosphoric acid:acetonitrile (50:50 v/v)

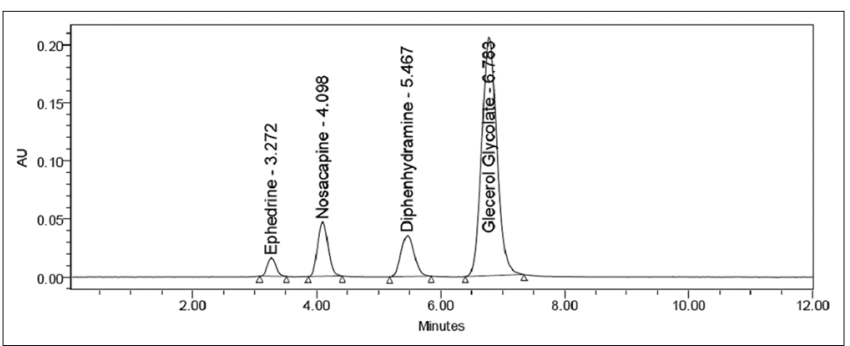

Fig. 1: Chromatogram showing the complete resolution of ephedrine, noscapine, diphenhydramine, and glycerol glycolate 
as the mobile phase. For good resolution and better separation, the flow rate of mobile phase was adjusted to $0.8 \mathrm{ml} / \mathrm{min}$. The chromatogram obtained with optimized conditions showing the separation of peaks due to ED, NP, DH, and GG is depicted in Fig. 1.

\section{Method validation}

The developed method is validated following guidelines as stated by ICH [10].

\section{System suitability}

The suitability of the system for the simultaneous analysis of ED, NP, $\mathrm{DH}$, and GG using the proposed method is evaluated after injection of six replicates of the standard solutions $(8 \mu \mathrm{g} / \mathrm{ml}-\mathrm{ED}, 15 \mu \mathrm{g} / \mathrm{ml}-\mathrm{NP}$, $12.5 \mu \mathrm{g} / \mathrm{ml}-\mathrm{DH}$, and $100 \mu \mathrm{g} / \mathrm{ml}$ - GG). The chromatograms were verified for each drug to calculate its retention time, plate count, peak area, peak tailing, and resolution [13]. The results revealed a \%RSD of $<1 \%$ for both peak areas and retention times. The other parameters of system suitability are well inside the endorsed limit. The accepted requirements are satisfied by this method and are shown in Table 1.

\section{Linearity}

Linearity was carried out by analyzing a series of calibration solutions in concentration range $2-12 \mu \mathrm{g} / \mathrm{ml}$ (ED), 3.75-22.5 $\mu \mathrm{g} / \mathrm{ml}$ (NP), $3.125-18.75 \mu \mathrm{g} / \mathrm{ml}(\mathrm{DH})$, and $25-150 \mu \mathrm{g} / \mathrm{ml}$ (GG). The chromatograms and peak area response were determined. The calibration curves obtained by marking peak area response of drugs versus concentration of drugs are presented in Fig. 2. The regression equations for ED, NP, DH, and GG were calculated using the corresponding calibration curve data (Table 2). The calibration curves, regression equations, and regression coefficient data revealed good linear ship between drug concentration and peak are a response.

\section{Limit of detection (LOD) and limit of quantification (LOQ)}

The sensitivity parameters, LOD and LOQ, for ED, NP, DH, and GG were established at a signal-to-noise ratio of 3:1 (LOD) and 10:1 (LOQ). The values are shown in Table 2 . The values revealed adequate sensitivity of the method for the simultaneous analysis of ED, NP, DH, and GG.

Table 1: System suitability testing parameters for the simultaneous determination of ED, NP, DH, and GG

\begin{tabular}{lllll}
\hline Suitability parameter & \multicolumn{2}{l}{ Mean value obtained for six determinations \pm RSD } & \multicolumn{2}{c}{ Recommended limit } \\
\cline { 2 - 5 } & ED & NP & DH & GG \\
\hline Retention time & $3.396 \pm 0.761$ & $4.215 \pm 0.500$ & $5.654 \pm 0.461$ & $7.214 \pm 0.878$ \\
Peak area & $208612 \pm 1.066$ & $752469 \pm 0.839$ & $697869 \pm 0.360$ & $4717995 \pm 0.551$ \\
Plate count & $2460 \pm 1.397$ & $2692 \pm 0.466$ & $2934 \pm 0.706$ & $3900 \pm 0.993$ \\
Resolution & - & $2.683 \pm 1.521$ & $3.867 \pm 1.336$ & $3.467 \pm 1.490$ \\
Peak tailing & $1.135 \pm 1.551$ & $1.138 \pm 1.027$ & $1.097 \pm 1.104$ & $1.093 \pm 0.472$ \\
\hline
\end{tabular}

ED: Ephedrine, NP: Noscapine, DH: Diphenhydramine, GG: Glycerol glycolate

Table 2: Linearity, regression, LOD and LOQ data for ED, NP, DH, and GG

\begin{tabular}{lllll}
\hline Parameter & \multicolumn{2}{l}{ Values obtained } & & DH \\
\cline { 2 - 5 } & ED & NP & $3.125-18.75$ & GG \\
\hline Linearity $(\mu \mathrm{g} / \mathrm{ml})$ & $2-12$ & $3.75-22.5$ & $\mathrm{~A}=54957 \mathrm{c}+11136$ & $\mathrm{~A}=45046 \mathrm{c}+79125$ \\
Regression equation $(\mathrm{A}=\mathrm{Sc}+\mathrm{I})$ & $\mathrm{A}=25525 \mathrm{c}+1148$ & $\mathrm{~A}=48451 \mathrm{c}+7848$ & 0.9994 & 0.9990 \\
Regression coefficient $\left(\mathrm{R}^{2}\right)$ & 0.9998 & 0.9992 & 54957 & 45046 \\
Slope $(\mathrm{S})$ & 25525 & 48451 & 11136 & 79125 \\
Intercept $(\mathrm{I})$ & 1148 & 7848 & 0.081 & 0.368 \\
LOD $(\mu \mathrm{g} / \mathrm{ml})$ & 0.060 & 0.062 & 0.246 & 1.114 \\
LOQ $(\mu \mathrm{g} / \mathrm{ml})$ & 0.181 & 0.187 & \\
\hline
\end{tabular}

ED: Ephedrine, NP: Noscapine, DH: Diphenhydramine, GG: Glycerol glycolate, LOD: Limit of detection, LOQ: Limit of quantification

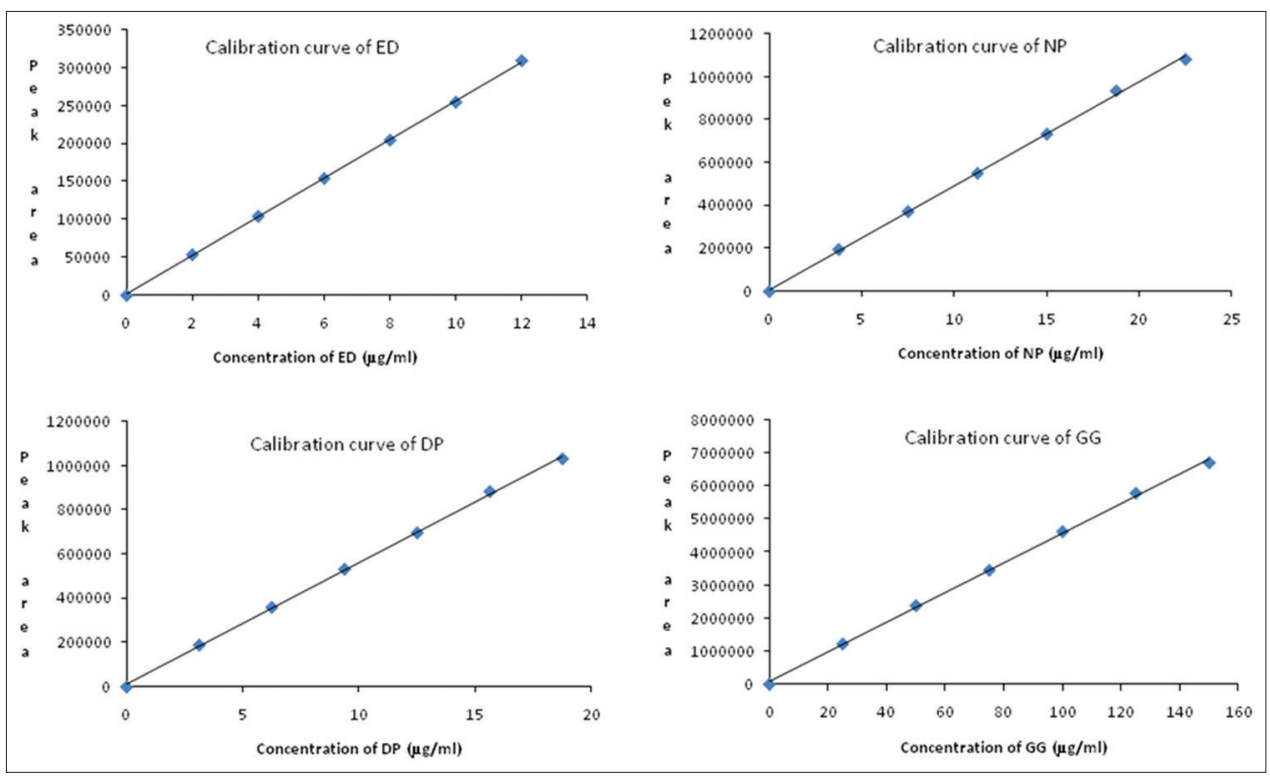

Fig. 2: Calibration curves of ephedrine, noscapine, DP, and glycerol glycolate 
Table 3: Intra- and inter-day precision data for ED, NP, DH, and GG

\begin{tabular}{|c|c|c|c|c|c|c|c|c|}
\hline \multirow[t]{2}{*}{ Injection No. } & \multicolumn{4}{|c|}{ Values obtained for intraday analysis } & \multicolumn{4}{|c|}{ Values obtained for interday analysis } \\
\hline & ED & NP & DH & GG & ED & NP & DH & GG \\
\hline 1 & 205,930 & 749,116 & 698,137 & 4699,457 & 193,700 & 724,380 & 648,381 & $4,525,401$ \\
\hline 3 & 207,031 & 753,579 & 694,389 & $4,760,524$ & 193,500 & 713,665 & 645,913 & $4,510,085$ \\
\hline 4 & 208,029 & 750,061 & 697,222 & $4,763,620$ & 191,696 & 718,623 & 653,035 & $4,476,993$ \\
\hline 5 & 209,944 & 746,996 & 695,790 & $4,697,301$ & 190,553 & 713,349 & 660,628 & $4,487,029$ \\
\hline 6 & 209,922 & 749,053 & 696,849 & $4,699,152$ & 192,642 & 723,808 & 659,289 & $4,440,562$ \\
\hline Mean & 208,348 & 749,439 & 695,265 & $4,720,154$ & 192,689 & 716,537 & 652,705 & $4,490,774$ \\
\hline$\%$ RSD & 0.788 & 0.306 & 0.465 & 0.689 & 0.699 & 1.009 & 0.932 & 0.667 \\
\hline
\end{tabular}

ED: Ephedrine, NP: Noscapine, DH: Diphenhydramine, GG: Glycerol glycolate

Table 4: Accuracy and recovery data for ED, NP, DH, and GG

\begin{tabular}{|c|c|c|c|c|c|c|c|c|c|}
\hline \multirow{2}{*}{$\begin{array}{l}\text { Labeled } \\
\text { claim (mg) }\end{array}$} & \multicolumn{3}{|l|}{$50 \%$ level } & \multicolumn{3}{|l|}{$100 \%$ level } & \multicolumn{3}{|l|}{$150 \%$ level } \\
\hline & Spiked (mg) & $\begin{array}{l}\text { Total } \\
\text { found (mg) }\end{array}$ & Assay (\%) & Spiked (mg) & $\begin{array}{l}\text { Total } \\
\text { found (mg) }\end{array}$ & Assay (\%) & Spiked (mg) & $\begin{array}{l}\text { Total } \\
\text { found (mg) }\end{array}$ & Assay (\%) \\
\hline \multicolumn{10}{|c|}{ Accuracy data of ED } \\
\hline 8 & 4 & 11.86 & 98.83 & 8 & 15.82 & 98.85 & 12 & 19.83 & 99.17 \\
\hline 8 & 4 & 11.95 & 99.58 & 8 & 15.91 & 99.45 & 12 & 19.86 & 99.32 \\
\hline 8 & 4 & 11.93 & 99.40 & 8 & 15.91 & 99.44 & 12 & 19.90 & 99.48 \\
\hline 15 & 7.5 & 22.32 & 99.21 & 15 & 30.13 & 100.45 & 22.5 & 37.24 & 99.31 \\
\hline 15 & 7.5 & 22.54 & 100.19 & 15 & 30.22 & 100.74 & 22.5 & 37.20 & 99.20 \\
\hline 15 & 7.5 & 22.41 & 99.60 & 15 & 30.25 & 100.85 & 22.5 & 37.41 & 99.75 \\
\hline \multicolumn{10}{|c|}{ Accuracy data of DH } \\
\hline 12.5 & 6.25 & 18.71 & 99.78 & 12.5 & 25.41 & 101.62 & 18.75 & 31.45 & 100.63 \\
\hline 12.5 & 6.25 & 18.79 & 100.19 & 12.5 & 25.04 & 100.14 & 18.75 & 31.48 & 100.75 \\
\hline 12.5 & 6.25 & 18.64 & 99.42 & 12.5 & 25.29 & 101.15 & 18.75 & 31.39 & 100.44 \\
\hline \multicolumn{10}{|c|}{ Accuracy data of GG } \\
\hline 100 & 50 & 150.38 & 100.25 & 100 & 199.37 & 99.69 & 150 & 250.25 & 100.10 \\
\hline
\end{tabular}

ED: Ephedrine, NP: Noscapine, DH: Diphenhydramine, GG: Glycerol glycolate

Table 5: Percent degradation of ED, NP, DH, and GG under different stress conditions

\begin{tabular}{|c|c|c|c|c|c|c|}
\hline \multirow[t]{3}{*}{ Condition applied } & \multicolumn{2}{|c|}{ Peak area } & \multirow[t]{3}{*}{ Degradation (\%) } & \multicolumn{2}{|l|}{ Peak area } & \multirow[t]{3}{*}{ Degradation (\%) } \\
\hline & WD & AD & & WD & AD & \\
\hline & \multicolumn{2}{|c|}{ Degradation data of ED } & & \multicolumn{2}{|c|}{ Degradation data of NP } & \\
\hline Acid & 208,612 & 196,502 & 5.99 & 752,469 & 700,944 & 7.03 \\
\hline Alkali & 208,612 & 199,492 & 4.56 & 752,469 & 708,533 & 6.03 \\
\hline Oxidation & 208,612 & 201,203 & 3.74 & 752,469 & 712,962 & 5.44 \\
\hline Dry heat & 208,612 & 203,929 & 2.44 & 752,469 & 730,975 & 3.05 \\
\hline \multirow{2}{*}{ Neutral } & 208,612 & 205,976 & 0.51 & 752,469 & 750,236 & 0.50 \\
\hline & \multicolumn{2}{|c|}{ Degradation data of DH } & & \multicolumn{2}{|c|}{ Degradation data of GG } & \\
\hline Acid & 697,869 & 656,528 & 6.02 & $4,717,995$ & $4,358,919$ & 7.70 \\
\hline Alkali & 697,869 & 658,498 & 5.74 & $4,717,995$ & $4,464,009$ & 5.48 \\
\hline Oxidation & 697,869 & 672,627 & 3.71 & $4,717,995$ & $4,584,918$ & 2.92 \\
\hline Dry heat & 697,869 & 677,905 & 2.96 & $4,717,995$ & $4,592,504$ & 2.76 \\
\hline UV light & 697,869 & 690,671 & 1.13 & $4,717,995$ & $4,659,410$ & 1.34 \\
\hline Neutral & 697,869 & 693,983 & 0.66 & $4,717,995$ & $4,682,368$ & 0.85 \\
\hline
\end{tabular}

WD: Without degradation, AD: After degradation, ED: Ephedrine, NP: Noscapine, DH: Diphenhydramine, GG: Glycerol glycolate

\section{Selectivity}

Selectivity was carried out to check the interference due to coeluting peaks (from mobile phase blank and placebo) at the retention times of ED, NP, DH, and GG. To confirm the method selectivity, placebo solution and mobile phase blank were injected into the chromatography system. The chromatograms from the placebo and mobile phase blank solutions were compared with the chromatograms of standard solution $(8 \mu \mathrm{g} / \mathrm{ml}$ - ED, $15 \mu \mathrm{g} / \mathrm{ml}$ - NP, $12.5 \mu \mathrm{g} / \mathrm{ml}-\mathrm{DH}$, and $100 \mu \mathrm{g} / \mathrm{ml}-\mathrm{GG})$ as well as the tablet sample solution $(8 \mu \mathrm{g} / \mathrm{ml}-\mathrm{ED}, 15 \mu \mathrm{g} / \mathrm{ml}-\mathrm{NP}$,
$12.5 \mu \mathrm{g} / \mathrm{ml}-\mathrm{DH}$, and $100 \mu \mathrm{g} / \mathrm{ml}$ - GG). The chromatograms in Fig. 3 demonstrated that there are no interferences from excipients used in placebo and components of mobile phase at the retention time of ED, NP, DH, and GG. This proved the selectivity of method for ED, NP, DP, and GG simultaneous analysis.

\section{Precision}

Intra- and inter-day precision was demonstrated by the analysis of standard solution with concentration $8 \mu \mathrm{g} / \mathrm{ml}$ (ED), $15 \mu \mathrm{g} / \mathrm{ml}$ (NP), 


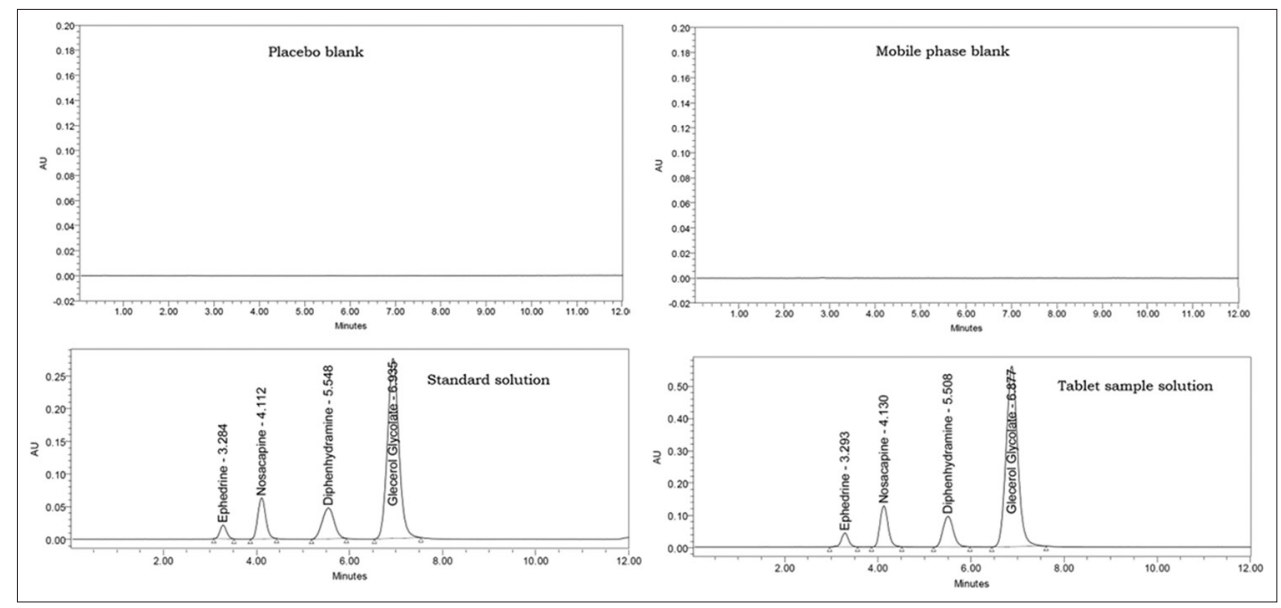

Fig. 3: Chromatograms demonstrating method selectivity
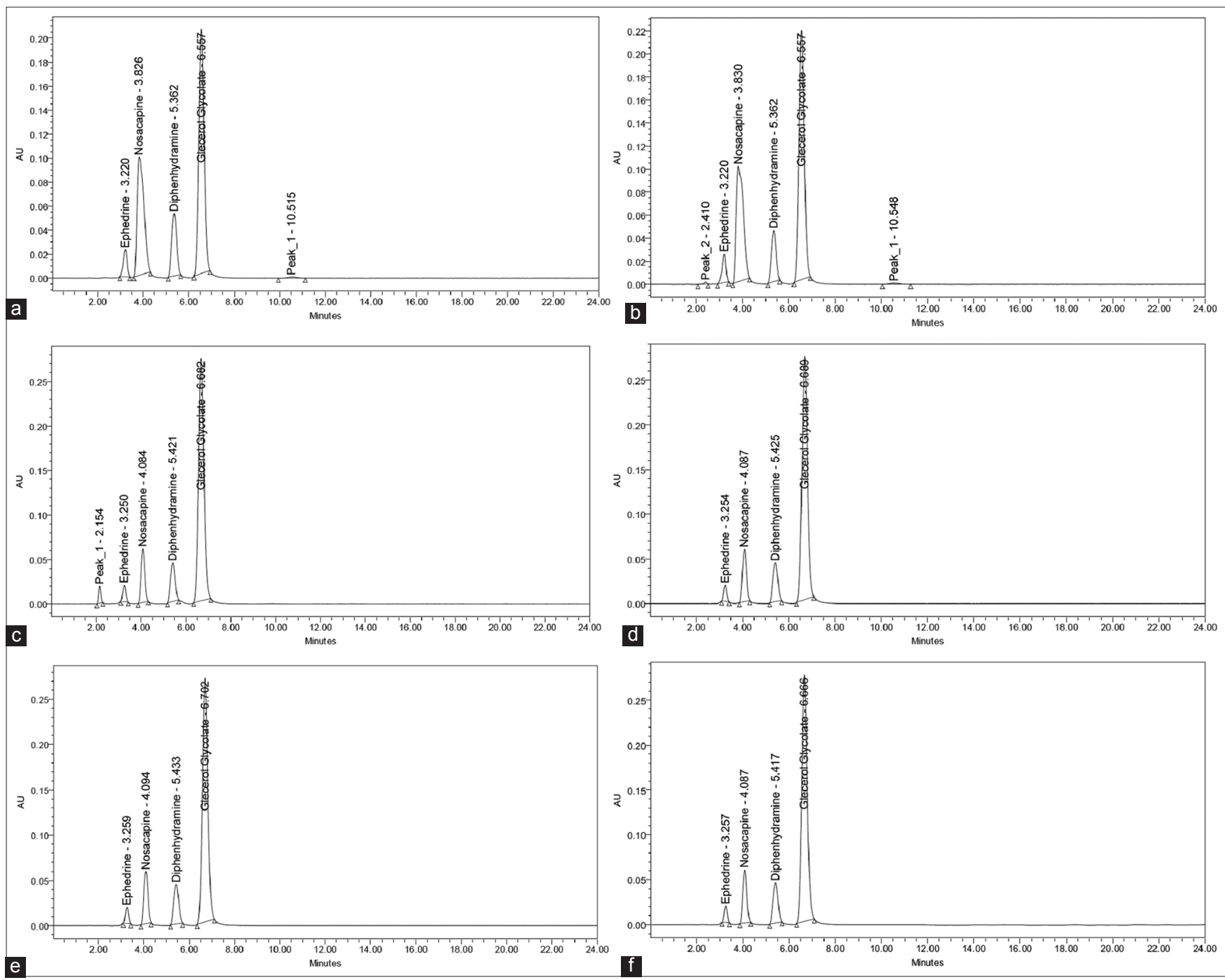

Fig. 4: Degradation chromatograms of tablet sample in (a) $2 \mathrm{~N} \mathrm{HCl}$, (b) $2 \mathrm{~N} \mathrm{NaOH,} \mathrm{(c)} 10 \% \mathrm{H}_{2} \mathrm{O}_{2}$, (d) Dry heat, (e) UV light, (f) Distilled water

$12.5 \mu \mathrm{g} / \mathrm{ml}(\mathrm{DH})$, and $100 \mu \mathrm{g} / \mathrm{ml}$ (GG) on the same day (intraday) and on two separate days (interday). For precision, the values of \%RSD for intra- and inter-day variation are given in Table 3 . The values were found to be good enough and $<2 \%$. This indicated the reproducibility and repeatability of the method.

\section{Accuracy and recovery}

For recovery, pre-analyzed tablet sample solution was spiked with pure ED, NP, DH, and GG at three concentration levels (50\%,100\%, and $150 \%$ of labeled claim). The resulting solution was analyzed 3 times using the propose method. For accuracy, the results were expressed 
Table 6: Results of the effect of small changes in method conditions on system suitability values of ED, NP, DH, and GG

\begin{tabular}{|c|c|c|c|c|c|c|c|}
\hline \multirow[t]{2}{*}{ Parameter } & \multirow[t]{2}{*}{ Value investigated } & PC & PT & Rs & PC & PT & Rs \\
\hline & & \multicolumn{3}{|c|}{ Robustness data of ED } & \multicolumn{3}{|c|}{ Robustness data of NP } \\
\hline Mobile phase* & $45: 55$ & 2212 & 1.09 & & 2581 & 1.13 & 2.5 \\
\hline \multirow[t]{2}{*}{ Flow rate $(\mathrm{ml} / \mathrm{min})$} & 0.7 & 2212 & 1.17 & - & 2376 & 1.17 & 2.7 \\
\hline & 0.9 & 3008 & 1.12 & - & 2275 & 1.18 & 2.6 \\
\hline \multirow[t]{2}{*}{ Temperature $\left(2^{\circ} \mathrm{C}\right)$} & 28 & 2260 & 1.05 & - & 2547 & 1.07 & 2.7 \\
\hline & 32 & 2451 & 1.03 & - & 2629 & 1.06 & 2.7 \\
\hline- & - & \multicolumn{3}{|c|}{ Robustness data of DH } & \multicolumn{3}{|c|}{ Robustness data of GG } \\
\hline \multirow[t]{2}{*}{ Mobile phase* } & $45: 55$ & 2784 & 1.03 & 3.3 & 3190 & 1.11 & 2.0 \\
\hline & $55: 45$ & 2689 & 1.05 & 4.0 & 3149 & 1.06 & 4.4 \\
\hline \multirow[t]{2}{*}{ Flow rate $(\mathrm{ml} / \mathrm{min})$} & 0.7 & 2626 & 1.11 & 3.5 & 3358 & 1.12 & 2.8 \\
\hline & 0.9 & 2550 & 1.15 & 3.5 & 3283 & 1.12 & 3.1 \\
\hline \multirow[t]{2}{*}{ Temperature $\left(2^{\circ} \mathrm{C}\right)$} & 28 & 2975 & 1.01 & 3.5 & 3302 & 1.08 & 2.2 \\
\hline & 32 & 3040 & 0.98 & 3.6 & 3493 & 1.09 & 2.4 \\
\hline
\end{tabular}

*Acetonitrile and $0.01 \mathrm{~N} \mathrm{KH}_{2} \mathrm{PO}_{4}$ buffer ratio; PC: Plate count, PT: Peak tailing, Rs: Resolution, ED: Ephedrine, NP: Noscapine, DH: Diphenhydramine, GG: Glycerol glycolate

Table 7: Assay of ED, NP, DH, and GG in Noscof tablet

\begin{tabular}{|c|c|c|c|c|}
\hline Drug & Labeled claim (mg) & Determined (mg)* & Assay (\%)* & RSD (\%) \\
\hline ED & 8 & 7.942 & 99.28 & 0.036 \\
\hline NP & 15 & 14.989 & 99.92 & 0.668 \\
\hline DH & 12.5 & 12.560 & 100.48 & 0.605 \\
\hline GG & 100 & 99.773 & 99.77 & 0.080 \\
\hline
\end{tabular}

*Average of three estimations, ED: Ephedrine, NP: Noscapine, DH: Diphenhydramine, GG: Glycerol glycolate

as percentage assay of ED, NP, DH, and GG in the samples. The overall results are demonstrated in Table 4, indicating the accuracy of the RPHPLC method developed.

\section{Degradation study}

The percent degradation of ED, NP, DH, and GG under different stress conditions applied is summarized in Table 5. Forced degradation study of tablet sample demonstrated that ED, NP, DH, and GG were more degraded in acid condition as compared with other applied stress conditions. The results also indicated that ED, NP, DH, and GG were observed to be more susceptible to neutral degradation condition than any other stress conditions. The chromatograms of degradation studies are shown in Fig. 4a-f. From the degradation chromatograms, the method specificity and stability indicating nature has proved since the peaks of degradation products are well resolved from the peaks of ED, NP, DH, and GG.

\section{Robustness}

Method robustness was determined through observing changes in the tailing factor, plate count, and plate count of ED, NP, DH, and GG when small and deliberate changes in flow rate $( \pm 1 \mathrm{ml} / \mathrm{min})$, mobile phase composition $( \pm 5 \%)$, and temperature $\left( \pm 2^{\circ} \mathrm{C}\right)$ of the optimized method are made. The results are summarized in Table 6. No significant impact on retention time, tailing factor and plate count of ED, NP, DH, and GG were observed. All the values are well inside the limits and hence proved the method robustness.

\section{Application of the proposed RP-HPLC method to assay ED, NP, DH, and GG simultaneously in Noscof tablet}

The content of ED, NP, DH, and GG in Noscof tablet was estimated using the developed RP-HPLC method. The results are presented in Table 7. The percent assay and percent relative, standard deviation values, showed that the developed RP-HPLC method provides a good degree of accuracy and reproducibility.

\section{CONCLUSION}

The developed RP-HPLC method with PDA is selective, precise, specific, and accurate for the quantification of ED, NP, DH, and GG simultaneously as bulk and in Noscof tablets devoid of any excipients interference. The method is also proved to be stability indicating one, as the peaks degradants formed during applied stress conditions were separated well from the ED, NP, DH, and GG peaks. The results obtained for the assay of ED, NP, DH, and GG in Noscof tablet revealed good accuracy and precision. Therefore, the proposed method is suitable for regular analysis in quality control laboratories.

\section{AUTHORS' CONTRIBUTIONS}

GSD designed and studied to successfully; PB performed the analysis, processed the experimental data, drafted the manuscript and designed the figures; GSD supervised the work.

\section{CONFLICTS OF INTEREST}

Authors, PB and GSD declare no conflicts of interest.

\section{REFERENCES}

1. Yvette CT. Monitoring Combination Drug Therapy. Available from: https://www.pharmacytimes.com/publications/issue/2010/january2010/ rxfocuscombination-0110. [Last accessed on $2010 \mathrm{Jan}$ 18].

2. Bangalore S, Kamalakkannan G, Parkar S, Messerli FH. Fixed-dose combinations improve medication compliance: A meta-analysis. Am J Med 2007;120:713-9.

3. Sun W, Sanderson PE, Zheng W. Drug combination therapy increases successful drug repositioning. Drug Discov Today 2016;21:1189-95.

4. Noscof (Ephedrine) Drug Price and Information. Medindia. Available from: https://www.medindia.net/drug-price/ephedrine/noscof.htm. [Last accessed on 2018 Nov 13]

5. Wong HC. Long-term use of diphenhydramine. CMAJ 2015;187:1078.

6. Ephedrine. Drug Information 2013. Bethesda, MD: American Society of Health-System Pharmacists; 2013. p. 1352.

7. Mahmoudian M, Mojaverian N. Efffect of noscapine, the antitussive opioid alkaloid, on bradykinin-induced smooth muscle contraction in the isolated ileum of the guinea-pig. Acta Physiol Hung 2001;88:231-7.

8. Glycerol Glycolate-Uses, Side-effects, Reviews, and PrecautionsTabletWise. Tabletwise. Available from: https://www.tabletwise.com/ medicine/glycerol-glycolate. [Last accessed on 2018 Nov 07].

9. Noscof Tablet-Uses, Side-Effects, Reviews, and Precautions-Medico Labs-Tabletwise-India, Tabletwise. Available from: https://www. 
tabletwise.com/noscof-tablet. [Last accessed on 2018 Nov 10].

10. International Conference on Harmonization (ICH). Validation of Analytical Procedures: Text and Methodology, Q2 (R1). Geneva, Switzerland: International Conference on Harmonization; 2005.

11. International Conference on Harmonization (ICH) of Technical Requirements for the Registration of Pharmaceutical for Human Use Stability Testing of New Drugs Substance and Products Q1A (R2),
Geneva, Switzerland; 2003.

12. Pradhan KK, Mishra US. Development and validation of a stability indicating RP-HPLC method for the determination of valsartan. Int J Pharm Pharm Sci 2015;7:57-61.

13. Bhoomaiah B, Shree AJ. Development and validation of RP-HPLC method for simultaneous determination of metformin and miglitol in bulk and pharmaceutical formulation. Int J Pharm Pharm Sci 2014;6:135-41. 